\title{
On the Source of Macroeconomic Fluctuations in the Middle Eastern and North African Countries: A Structural Vector Autoregression Analysis
}

\author{
Ph.D. Candidate Evrim Toren (Eastern Mediterranean University, Cyprus)
}

\begin{abstract}
This study investigates the relative importance of various shocks in accounting for output fluctuations in the Middle East and North Africa (MENA) countries. The macroeconomic shocks are decomposed into countryspecific, regional, and global sources by using a small open economy structural vector autoregression (SVAR) model. In order to explain output volatility in Middle East and North Africa, the relative importance of each shock in 15 MENA countries is identified in this study. The results show that country-specific factors account for most of the output volatility in the region. For less than half of the countries in the region, global shocks play a significant role in explaining output volatility. Contrary to some findings in the empirical literature, especially on Sub-Saharan Africa, the regional factor does not seem to have a statistically significant impact in any of the countries under consideration. The results are uniform and no statistically significant difference is observed for the countries in the MENA region. Furthermore, oil-exporting and oil-poor countries in the sample do not show any noticeable difference.
\end{abstract}

\section{Introduction}

Until recently, the impact of output fluctuations on economic growth and welfare was generally assumed to be negligible and therefore not a major concern. However, more recent macroeconomic literature, especially following the East Asian crisis of the late 1990s, suggests that high output volatility could have significant adverse effects on long-term growth and welfare (Aizernman and Pinto, 2000; Kose, et al., 2005). The transmission mechanisms between output volatility and long-term economic performance are complex, varied, and not sufficiently understood (Hakura, 2007). One theory argues that, output volatility, by increasing the uncertainty about future returns, could significantly reduce investment and therefore growth. On the other hand, there are those that argue that, volatility could have beneficial effects on growth (Blackburn, 1999; Tornell, et al., 2004).

Output volatility could also adversely affect poverty in developing countries like those in Middle East and North Africa, MENA. Given that fiscal policy is pro-cyclical in most developing countries, this magnifies the negative impact of volatility on poverty especially during crisis. Recent empirical research finds that volatility has significantly negative and causal impact on poverty (Laursen and Mahajan, 2005). The adverse effect of volatility seems to be more pronounced in low-income MENA countries and Sub-Saharan Africa. Periods of extreme volatility have been associated with increased poverty and a concomitant worsening of income distribution in emerging markets. In addition, the poor often lack necessary education and skills, limiting their ability to move across sectors to adjust to changes in economic conditions.

A central concern of this study is whether the source of volatility matters for growth. It is generally recognized in the macroeconomic literature that shocks play a crucial role in predicting national and international business cycles and output volatility. A growing area of research is the relative role played by global, regional, and country specific shocks in accounting for domestic output fluctuations. In recent years, understanding and decomposing the various factors affecting the short and long run behaviour of output volatility in the MENA region has become a rapidly growing area of research. Some studies have focused on the determinants of economic growth (Abed and Davoodi, 2003; Makdisi, et al., 2003, Hakura, 2004; Tamberi, 2005) while others consider how increasing trade and financial linkages affect various economic outcomes in the region (Abed and Davoodi, 2003; Hirata, et al., 2004). More recent studies document the main features of business cycles in the MENA countries (Hirata, et al., 2004; Süssmuth and Woitek, 2004; Lucke, 2004; Al Zoubi and Meghyereh, 2005; Hirata, et al., 2007). Shafik (1998) focuses on the dynamics of economic growth, transitional issues, poverty, and environment in the MENA region. Iqbal (2001) focuses on a range of issues from demographic transition to financial liberalization in the region. The volatile changes in the MENA region during the last three decades have lead to controversies on the relative importance of potential sources of macroeconomic fluctuations. Several studies attribute a significant role to terms of trade shock and external linkages (Makdisi et al., 2003; Diboglu and Alesia, 2004; Hirata et al., 2004, 2007). Using a similar structural vector autoregressive (SVAR) model approach as in this study, Hoffmaisterand Roldos (1997), and Ahmed and Loungani (1998) examine the sources of macroeconomic fluctuations in developing countries and find that terms of trade and world output shocks play a significant role. Mehrara and Oskoui (2007)used a SVAR model to examine the sources of macroeconomic fluctuations in five oil-exporting MENA countries. They found that oil price shocks were the main source of output fluctuations in Saudi Arabia and Iran but not in Kuwait and Indonesia. Some 
other studies point to the significant role played by real demand shocks such as fiscal imbalances and real exchange rate misalignments, in countries of the MENA region (Domac and Shabsigh, 2001; Nashashibi, et al., 2001; Jalali-Naini, 2000).

This study primarily focuses on investigating the sources of output volatility in the MENA region. There is a growing view in the literature that external shocks play a crucial role in accounting for business cycle in the region. Monetary policy is also assumed to have been destabilizing for a long time. Using a small open-economy model appropriate to the MENA region, this study examines the relative importance of external shocks (regional and global) as well as domestic shocks in accounting for output volatility. The rest of the paper is organised as follows. Section 2 outlines the approach used to investigate the sources of output volatility in the MENA countries. Section 3 presents the empirical results derived from the impulse response analysis of shocks and their variance decompositions. Section 4 concludes the discussion.

\section{A SVAR Model of Business Cycle with Global and Regional Shocks}

In order to study the sources of business cycle in the MENA region, this study includes the structural vector autoregression (SVAR) approach proposed by Blanchard and Quah (1989) and extended to open economies by Ahmed et al. (1993), Bjørnland (1998), and Hoffmaister and Roldós (2001). The output volatility is decomposed into three sources, namely; country-specific, regional, and global shocks. Since all variables used in this study are found to be nonstationary, a SVAR model is specified in the first differences. Due to data limitations, 15 countries are included in this study. These include 10 countries (Bahrain, Iran, Israel, Jordan, Kuwait, Libya, Oman, Saudi Arabia, Syria, United Arab Emirates) in the Middle East and 5 countries (Algeria, Egypt, Malta, Morocco, Tunisia) in North Africa. The model incorporates three sources of business cycle: effects of shocks from world output, regional output, and domestic output. To be consistent with the assumption of a small open economy, domestic shocks are not allowed to affect the global and regional variables.

As noted above, the model identifies three structural shocks. The external shocks are the shocks in the global output growth and the regional output growth. Phillips (1991), an extension of Hamilton (1989), gives an example of what can be interpreted as a global shock. Particularly in the Middle East, there might be regional shocks due to past wars. There is a long debate in the literature for an African factor. The African factor may be interpreted as one example of a regional shock. The model identifies one country specific shock, which is productivity shock in the home country. It may be difficult to identify the country specific shocks as either supply or demand shocks. Glick and Rogoff (1995), identify country specific shocks as deviation of Solow residual from world aggregate productivity measure; thus Glick and Rogoff's view is adopted in this study. In the model, country specific shocks include supply shocks possibly including structural reforms such as tariff and trade reforms, relative demand shocks arising from changes in public spending/debt and relative preferences, and aggregate demand shock. The latter captures the effects of nominal variables.

Ordinary least squares (OLS) is used not only to estimate a finite order vector autoregression (VAR) but also to obtain the moving average representation. It is assumed that the global supply and regional shocks have no long run effect on the differential of output level of a country from the world and regional output, respectively. Additionally, the study requires that the global supply shocks have no long-run impact on the deviation of a country's output from the regional output. It is reasonable to assume that in the long-run global shocks will have the same impact across the region. With the just identification of the structural shocks, the SVAR model is used to evaluate the impulse responses and variance decompositions.

\section{Empirical Findings}

In this study, data set contains annual data from 1960 to 2007, but the sample period varies for some countries depending on data availability. Descriptive statistics, sample period and number of observations are given in Table 1. All data, except the crude oil price, were obtained from the World Development Indicators (WDI). The crude oil price data were taken from the British Petroleum Statistical Review of World Energy Workbook. The data set includes 15 countries, 10 countries (Bahrain, Iran, Israil, Jordan, Kuwait, Libya, Oman, Saudi Arabia, Syria, United Arab Emirates) in the Middle East and 5 countries (Algeria, Egypt, Malta, Morocco, Tunisia) in North Africa. The selection of these countries was based on data availability. All variables are measured in a logarithmic scale. The unit root test shows that all the variables are nonstationary in levels and stationary in first differences. Therefore, the SVAR is estimated in first difference form for all countries. For each country, a trivariate SVAR model is estimated as specified in Section 2.

This study determines the appropriate lag length by usingthe reduced form VAR model. The model is estimated by restricting the lag length between one and four. On the basis of the Bayesian (BIC) and the HannanQuinn (HQ) Information Criteria (HQ), the sample evidence for the entire reduced form VAR system suggested a lag length of 1 for all countries, except Malta and Saudi Arabia for which a lag length of 2 is selected. A series of sequential likelihood ratio tests for a shorter lag length versus a longer lag length, suggested also a lag length of 
one. The $p$-value of the Portmanteau test for residual autocorrelation ranges from 0.06 to 0.56 for a lag length of 8 and 0.04 to 0.42 for a lag length of 16 . The normality of the residuals is not rejected using the multivariate normality test of Doornik and Hansen (1994). Given that the evidence for residual autocorrelation is weak and sample sizes were mostly around 48; the VAR models are estimated with a lag length of one for all countries.

Given the potential for structural breaks in the sample, conditional on constant variances, the parameter stability of each equation in the VAR models is tested. When a series of Wald-tests are performed, this study shows that these tests, conditional on constant variances, do not suggest evidence of parameter instability in general. The Chow break point test does not also suggest parameter instability. However, parameter stability is rejected for Libya and Jordan.

In order to show the validity of the structure of the SVAR model, the impulse response functions are estimated (Hamilton, 1994). Each variable in this model is expressed as a combination of current and all past errors. Thedynamic response of domestic real GDP to a one standard deviation innovation is examined in the three structural shocks. The cumulative impulse responses of domestic output to a one-standard-deviation positive innovation in each structural shock are given in Figure 1. The impulse response functions are normalized such that zero represents the steady-state value of the response variable. Several observations are in order. Consider first the impulse response to a positive country-specific shock. A positive country specific productivity shock raises the domestic output permanently in all countries. Responses to country specific shock are relatively much larger than responses to regional and global shocks. In terms of the response to country specific shock there is no difference between the oil-rich and oil-poor countries. It is also observed that the Middle East and North African countries are also analogous.

\begin{tabular}{lllllll}
\hline Country & Period & Mean & Median & Maximum & Minimum & Std. Dev. \\
\hline Algeria & $1960-2007$ & 174 & 193 & 336 & 44.2 & 81.3 \\
Bahrain & $1980-2007$ & 2.39 & 2.3 & 4.57 & 1.29 & 0.96 \\
Egypt & $1960-2007$ & 109 & 97.7 & 275 & 10 & 72.2 \\
Iran & $1965-2007$ & 240000 & 221000 & 482000 & 77000 & 95600 \\
Israel & $1960-2007$ & 281 & 238 & 652 & 52.8 & 173 \\
Jordan & $1975-2007$ & 4.22 & 3.83 & 8.23 & 1.3 & 1.77 \\
Kuwait & $1962-2007$ & 7.35 & 6.86 & 14.3 & 4.64 & 2.24 \\
Libya & $1960-1987$ & 3.71 & 4.09 & 5.94 & 0.65 & 1.5 \\
Malta & $1960-2007$ & 0.32 & 0.28 & 0.68 & 0.06 & 0.21 \\
Morocco & $1960-2007$ & 257 & 231 & 552 & 77.9 & 135 \\
Oman & $1960-2007$ & 2.93 & 2.52 & 7.88 & 0.15 & 2.33 \\
Saudi Arabia & $1968-2007$ & 486 & 484 & 813 & 125 & 172 \\
Syria & $1960-2007$ & 538 & 502 & 1270 & 105 & 338 \\
Tunisia & $1961-2007$ & 9.89 & 8.86 & 24 & 2.36 & 6.05 \\
United Arab Emirates & $1973-2007$ & 155 & 136 & 348 & 53.5 & 74 \\
\hline
\end{tabular}

\begin{tabular}{lllllll}
\hline Country & Period & Skewness & Kurtosis & JB & $\mathrm{p}$ & $\mathrm{n}$ \\
\hline Algeria & $1960-2007$ & 0.1 & 2.05 & 1.87 & 0.39 & 48 \\
Bahrain & $1980-2007$ & 0.69 & 2.42 & 2.6 & 0.27 & 28 \\
Egypt & $1960-2007$ & 0.61 & 2.22 & 4.16 & 0.12 & 48 \\
Iran & $1965-2007$ & 0.61 & 3.09 & 2.69 & 0.26 & 43 \\
Israel & $1960-2007$ & 0.53 & 2.1 & 3.89 & 0.14 & 48 \\
Jordan & $1975-2007$ & 0.52 & 2.64 & 1.65 & 0.44 & 33 \\
Kuwait & $1962-2007$ & 1.34 & 4.55 & 18.34 & 0 & 46 \\
Libya & $1960-1987$ & -0.72 & 2.61 & 2.62 & 0.27 & 28 \\
Malta & $1960-2007$ & 0.32 & 1.71 & 4.17 & 0.12 & 48 \\
Morocco & $1960-2007$ & 0.47 & 2.22 & 2.98 & 0.23 & 48 \\
Oman & $1960-2007$ & 0.48 & 1.97 & 3.97 & 0.14 & 48 \\
Saudi Arabia & $1968-2007$ & -0.36 & 2.85 & 0.92 & 0.63 & 40 \\
Syria & $1960-2007$ & 0.46 & 2.06 & 3.43 & 0.18 & 48 \\
Tunisia & $1961-2007$ & 0.65 & 2.4 & 4.01 & 0.13 & 47 \\
United Arab & $1973-2007$ & 1.01 & 3.36 & 6.14 & 0.05 & 35 \\
Emirates & & & & & & \\
\hline
\end{tabular}

Table 1: Descriptive statistics for real GDP. JB is the Jarque-Berra statistics for normality, $p$ is the $p$ value for the JB test and $n$ is the number of observations. GDP is measured in billions of local currency unit. 

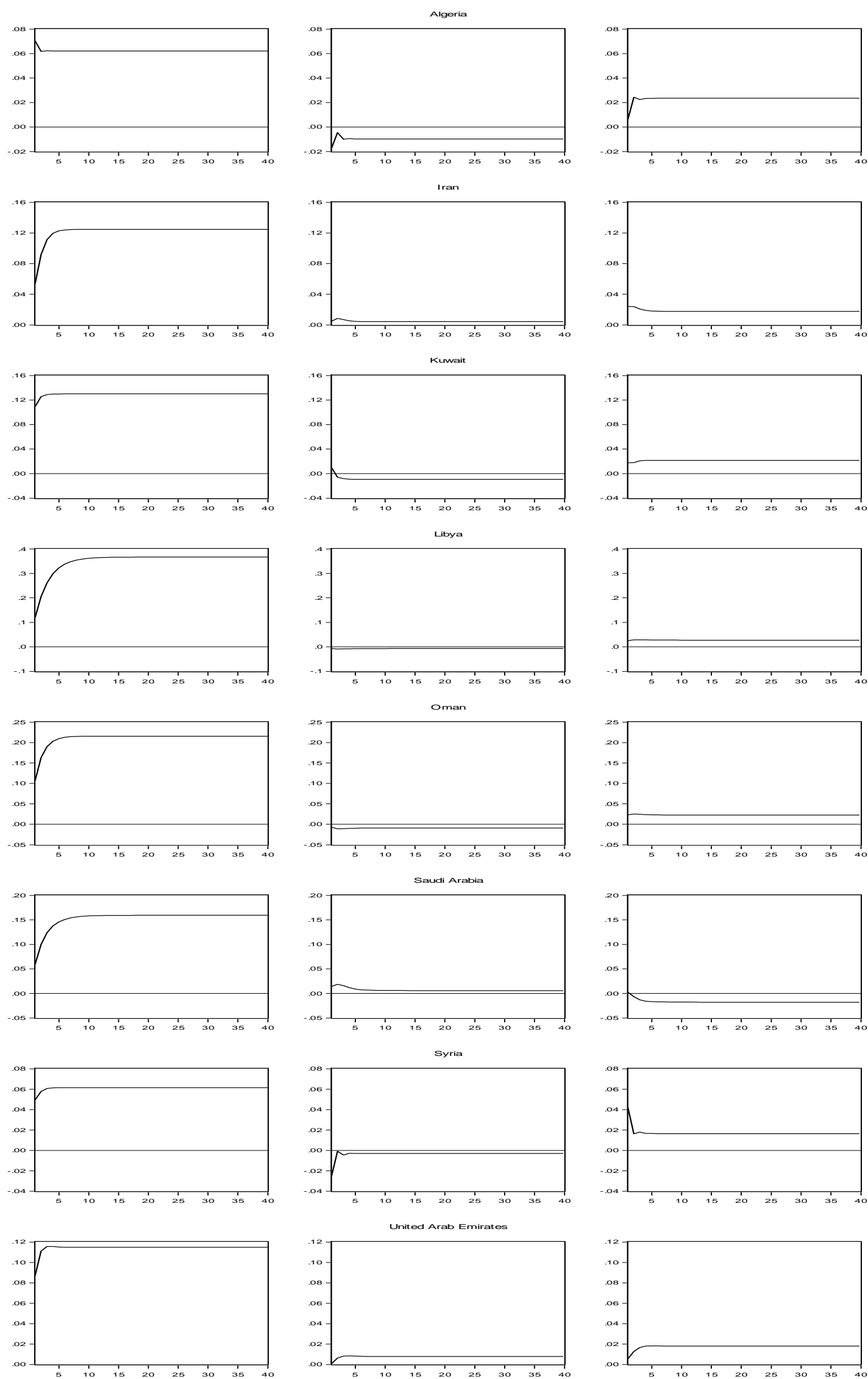

Figure 1. Impulse responses of domestic output: Oil rich countries are represented orderly for country specific shock, regional shock and global shock 

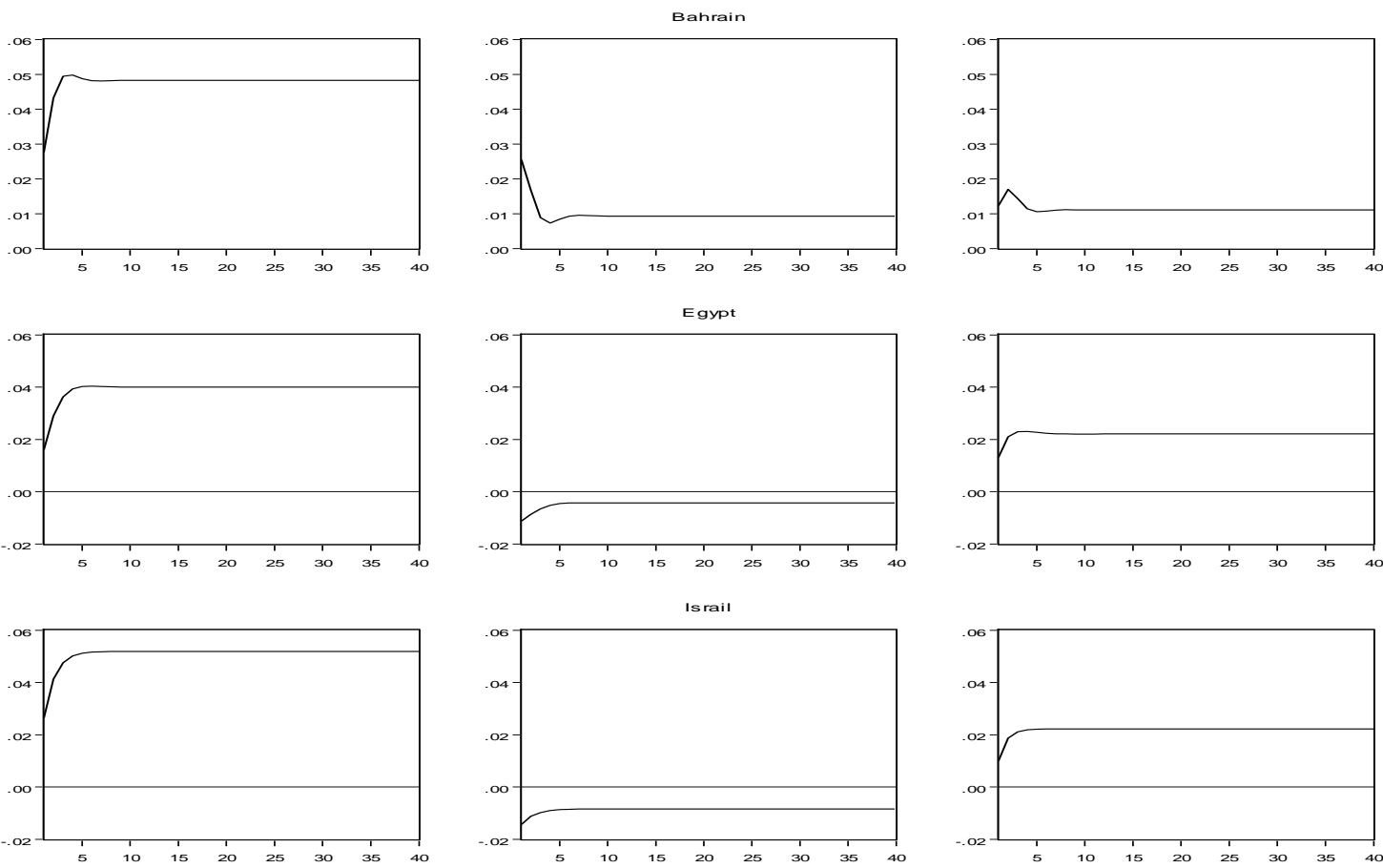

Is rai
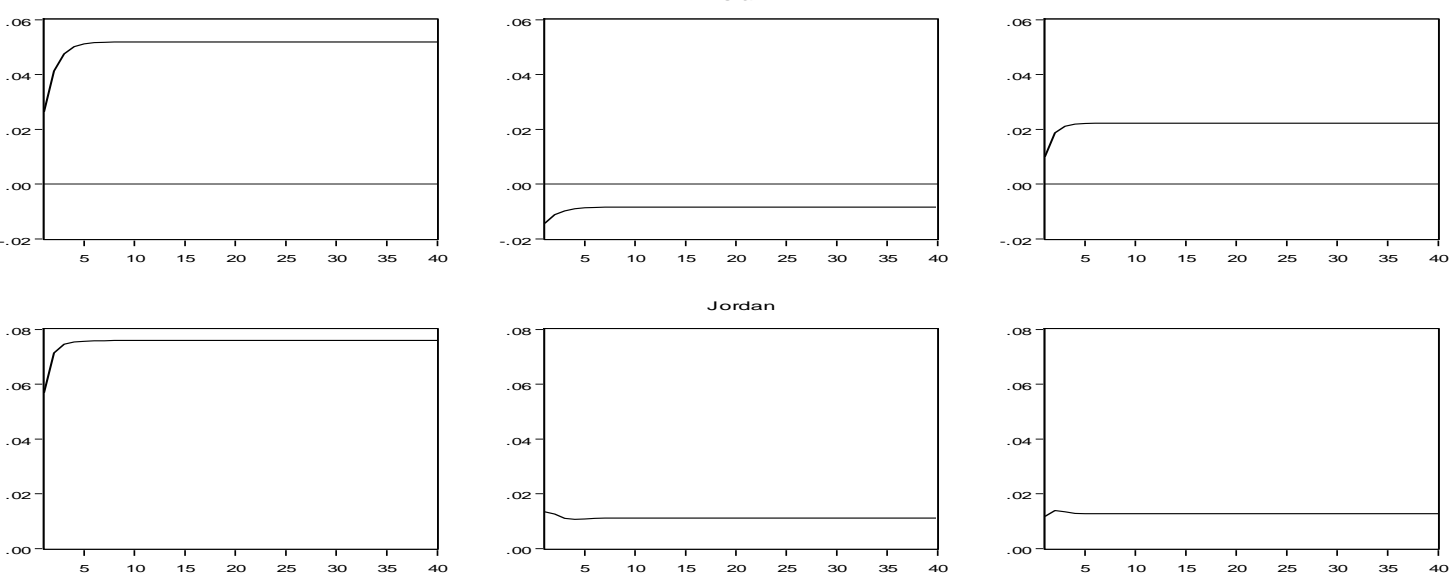

Jordan
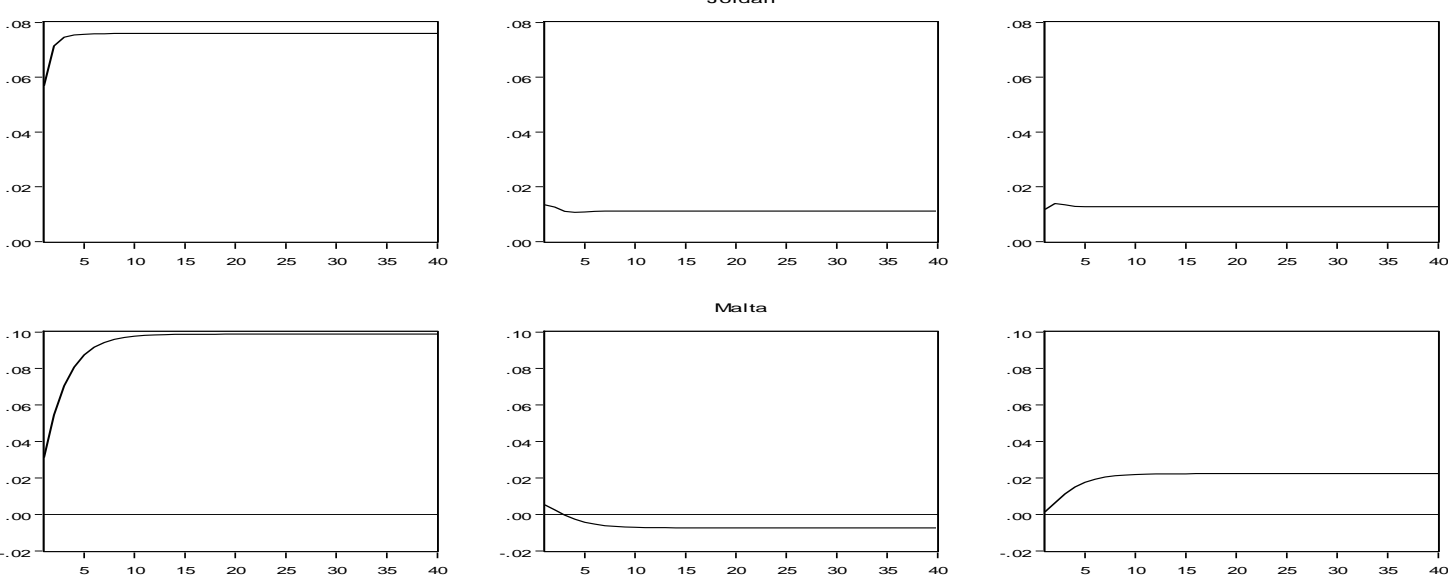

Malta
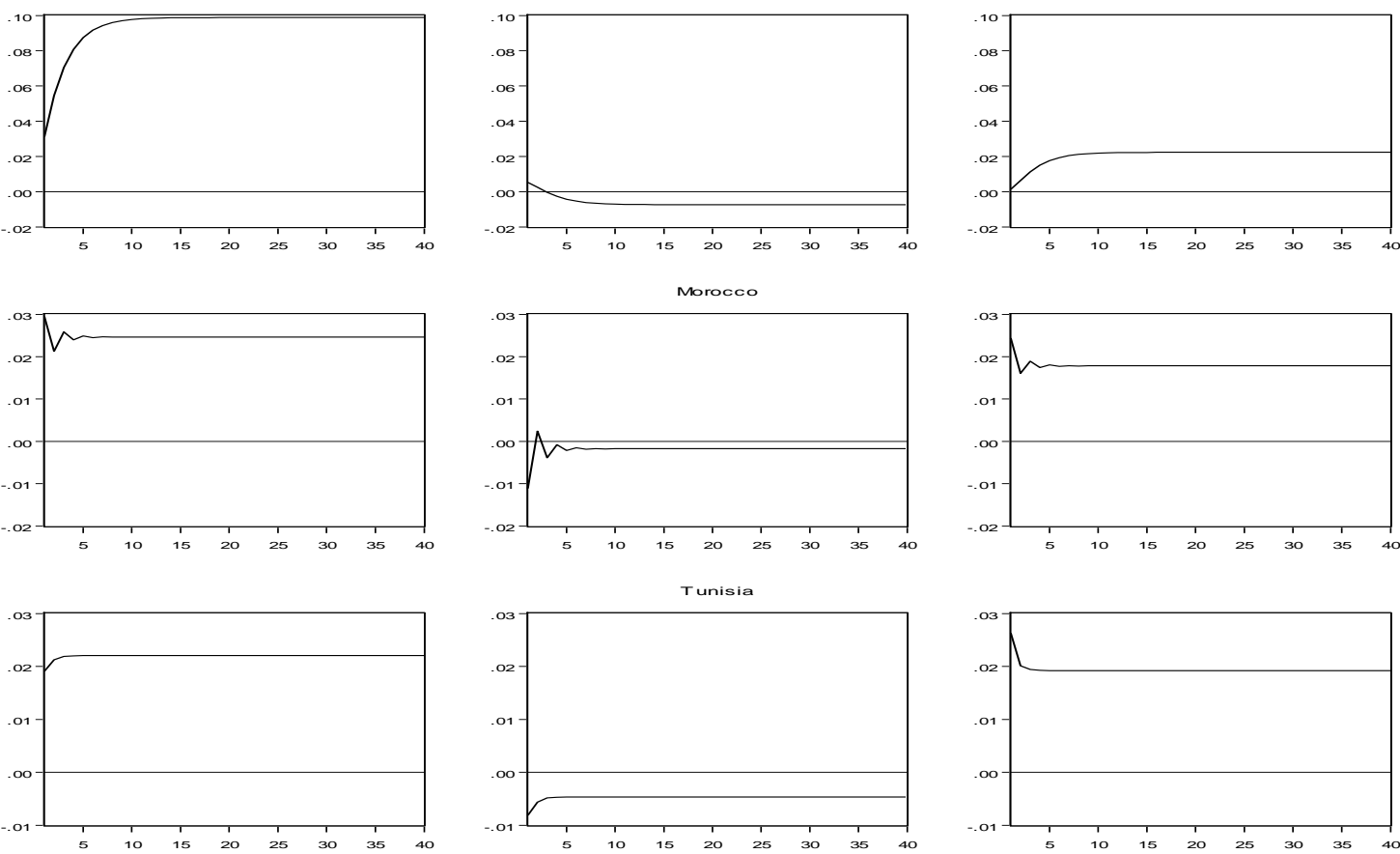

Figure 2. Impulse responses of domestic output: oil poor countries are presented orderly for country specific shock, regional shock and global shock 


\begin{tabular}{|c|c|c|c|c|c|c|c|c|}
\hline $\begin{array}{l}\begin{array}{l}\text { Period } \\
\text { (years) }\end{array} \\
\end{array}$ & s.e. & $\begin{array}{l}\text { Home } \\
\text { Shock }\end{array}$ & $\begin{array}{l}\text { Regional } \\
\text { Shock }\end{array}$ & $\begin{array}{l}\text { Global } \\
\text { Shock }\end{array}$ & s.e. & $\begin{array}{l}\text { Home } \\
\text { Shock }\end{array}$ & $\begin{array}{l}\text { Regional } \\
\text { Shock }\end{array}$ & $\begin{array}{l}\text { Global } \\
\text { Shock }\end{array}$ \\
\hline & \multicolumn{4}{|c|}{ Malta } & \multicolumn{4}{|l|}{ Syria } \\
\hline 1 & 0.04 & 97.12 & 2.70 & 0.18 & 0.07 & 50.44 & 13.02 & 36.54 \\
\hline 2 & 0.04 & 96.25 & 2.12 & 1.63 & 0.09 & 40.67 & 19.71 & 39.62 \\
\hline 3 & 0.05 & 95.02 & 2.25 & 2.73 & 0.09 & 40.65 & 19.84 & 39.51 \\
\hline 4 & 0.05 & 94.34 & 2.39 & 3.28 & 0.09 & 40.62 & 19.87 & 39.51 \\
\hline 5 & 0.05 & 94.02 & 2.46 & 3.52 & 0.09 & 40.62 & 19.87 & 39.51 \\
\hline 6 & 0.05 & 93.88 & 2.49 & 3.63 & 0.09 & 40.62 & 19.87 & 39.51 \\
\hline 10 & 0.05 & 93.79 & 2.51 & 3.70 & 0.09 & 40.62 & 19.87 & 39.51 \\
\hline 20 & 0.05 & 93.79 & 2.51 & 3.70 & 0.09 & 40.62 & 19.87 & 39.51 \\
\hline \multirow[t]{2}{*}{40} & 0.05 & 93.79 & 2.51 & 3.70 & 0.09 & 40.62 & 19.87 & 39.51 \\
\hline & \multicolumn{4}{|c|}{ Morocco } & \multicolumn{4}{|c|}{ Tunisia } \\
\hline 1 & 0.05 & 54.77 & 7.78 & 37.45 & 0.04 & 32.36 & 5.90 & 61.74 \\
\hline 2 & 0.05 & 49.14 & 16.03 & 34.83 & 0.04 & 31.40 & 6.17 & 62.44 \\
\hline 3 & 0.05 & 48.50 & 17.44 & 34.06 & 0.04 & 31.39 & 6.22 & 62.39 \\
\hline 4 & 0.05 & 48.31 & 17.77 & 33.92 & 0.04 & 31.39 & 6.22 & 62.39 \\
\hline 5 & 0.05 & 48.28 & 17.83 & 33.89 & 0.04 & 31.39 & 6.22 & 62.39 \\
\hline 6 & 0.05 & 48.27 & 17.85 & 33.88 & 0.04 & 31.39 & 6.22 & 62.39 \\
\hline 10 & 0.05 & 48.27 & 17.85 & 33.88 & 0.04 & 31.39 & 6.22 & 62.39 \\
\hline 20 & 0.05 & 48.27 & 17.85 & 33.88 & 0.04 & 31.39 & 6.22 & 62.39 \\
\hline \multirow[t]{2}{*}{40} & 0.05 & 48.27 & 17.85 & 33.88 & 0.04 & 31.39 & 6.22 & 62.39 \\
\hline & \multicolumn{4}{|l|}{ Oman } & \multicolumn{4}{|c|}{ United Arab Emirates } \\
\hline 1 & 0.11 & 95.22 & 0.45 & 4.33 & 0.09 & 99.61 & 0.01 & 0.38 \\
\hline 2 & 0.13 & 96.08 & 0.44 & 3.48 & 0.09 & 98.64 & 0.36 & 1.00 \\
\hline 3 & 0.13 & 96.26 & 0.42 & 3.32 & 0.09 & 98.41 & 0.41 & 1.17 \\
\hline 4 & 0.13 & 96.29 & 0.42 & 3.28 & 0.09 & 98.39 & 0.41 & 1.19 \\
\hline 5 & 0.13 & 96.30 & 0.42 & 3.28 & 0.09 & 98.39 & 0.41 & 1.19 \\
\hline 6 & 0.13 & 96.30 & 0.42 & 3.28 & 0.09 & 98.39 & 0.41 & 1.19 \\
\hline 10 & 0.13 & 96.30 & 0.42 & 3.28 & 0.09 & 98.39 & 0.41 & 1.19 \\
\hline 20 & 0.13 & 96.30 & 0.42 & 3.28 & 0.09 & 98.39 & 0.41 & 1.19 \\
\hline \multirow[t]{2}{*}{40} & 0.13 & 96.30 & 0.42 & 3.28 & 0.09 & 98.39 & 0.41 & 1.19 \\
\hline & \multicolumn{4}{|c|}{ Saudi Arabia } & & & & \\
\hline 1 & 0.06 & 94.44 & 5.42 & 0.14 & & & & \\
\hline 2 & 0.07 & 94.40 & 4.11 & 1.50 & & & & \\
\hline 3 & 0.08 & 94.14 & 3.82 & 2.05 & & & & \\
\hline 4 & 0.08 & 93.93 & 3.96 & 2.10 & & & & \\
\hline 5 & 0.08 & 93.87 & 4.04 & 2.09 & & & & \\
\hline 6 & 0.08 & 93.86 & 4.06 & 2.08 & & & & \\
\hline 10 & 0.08 & 93.86 & 4.06 & 2.08 & & & & \\
\hline 20 & 0.08 & 93.86 & 4.06 & 2.08 & & & & \\
\hline 40 & 0.08 & 93.86 & 4.06 & 2.08 & & & & \\
\hline
\end{tabular}

Table 2.Forecast error variance decomposition of domestic real GDP

Cumulative impulse responses to a one standard deviation positive regional shock are given in the second column of Figure 2. The responses to regional shocks are surprisingly small at all horizons uniformly across all countries. Although responses to regional shock are insignificant for all countries some show a little insignificant negative response while others have positive but insignificant response. Thus regional factors seem to play no role in accounting for output volatility in the MENA region. In terms of responses toregional shocks, oil-rich, oil-poor, Middle East, and North Africa countries are highly similar. Our findings indicate that the regional factor play almost no role in explaining macroeconomic volatility in the MENA region. Our result further confirms the findings by Kose et al. (2003) and Berument et al. (2007) for countries from all regions of the world, although their study is based on a different approach. 
Impulse responses to global shocks in the MENA region are shown in the third column of Figure 1. The result indicates that the responses are not significant for most countries. However, the result is not so uniform as in the case of country-specific and regional shocks. Among the oil-rich countries, Algeria, Syria, and United Arab Emirates show some mild positive permanent response to positive global shock. However, these are relatively much smaller than the responses to country-specific shocks. Thus, majority of oil-exporting countries do not show significant response to global shocks. In contrast to oil-rich countries, almost all oil poor countries show significant response to global shocks. Positive global productivity shocks permanently raise the output in these countries. Among these countries Egypt, Israel, Morocco, and Tunisia show quite large responses. The responses in Tunisia are almost as large as the response to country specific shocks. Thus, global shocks seem to play some role for oil poor countries, mostly for those in North Africa. Some of these economies are more integrated to world economies than those who done show significant response.

In order to measure the quantitative importance of the relative contributions of the world, regional, and country-specific factors to variations in output fluctuations in each country are estimated. The variance of domestic output at different horizons is decomposed into the fraction that is due to each of the three factors. The forecast error variance decompositions of domestic output are given in Table 2 along with their standard errors. The forecast error variance decompositions show the variance of domestic output attributable to countryspecific, regional, and global shocks at horizons 1-6, 10, 20, and 40. The variance components add up to 100 percent so that all volatility in domestic output can be attributed to country-specific, regional and global factors.

The variance decompositions show that the country-specific factors play a much larger role in accounting for output dynamics than the world and region factors. The country-specific factors explain more than 70 percent of output fluctuations for 10 countries, and the global shocks account for more than 50 percent of output volatility for 4 countries. The world and regional factors combined account for less than 40 percent of output volatility in 9 countries. For Bahrain, Egypt, Israel, Morocco, and Syria regional factors account for 16 percent of output volatility, while for the corresponding figure for Bahrain is 40 percent. Global shocks account for a significant fraction of output volatility in Egypt (27\%), Israel (13\%), Morocco (34\%), Syria (40\%), and Tunisia (62\%). In summary, the variance decompositions show that that the regional factors play a minor role in explaining output volatility in the MENA region with the exception of Bahrain. Global factors play the second important role after country-specific factors. However, only for one country global shocks dominate the country-specific shocks, which is Tunisia. Overall, country-specific factors account for more than $50 \%$ percent of the output fluctuations at all horizons for 14 countries out of the 15 countries in the region. Further, the results show no significant difference for the Middle East and North Africa. There is also no noticeable difference between oil-rich and oilpoor countries.

\section{Conclusion}

This study attempts to assess the relative importance of country-specific, regional, and global shocks in output fluctuations for the MENA countries. A small open economy SVAR model is used to show that business-cycle fluctuations are driven by country-specific, regional, and global shocks. The model uncovers valuable information about the response of domestic output to country-specific, regional, and global factors. Some of the results contradict the conventional wisdom in the region. In accordance with the small open economy assumption, and to disentangle the effects of external shocks from domestic shocks, it is assumed that the global shocks are not affected by regional and country-specific shocks. Regional shocks are also assumed to be unaffected by country specific shocks. One of the virtues of this approach is that it identifies and measures the effect of different types of shocks in a unified framework.

The research findings show that for all countries under consideration, domestic output volatility is mostly accounted for by country-specific factors. In about one-third of the countries, global shocks play a significant role in output fluctuations. Regional factors do not play a significant role for any of the countries. Although several studies found that regional factors might be an important factor in output volatility, the results found no statistical evidence in support of these studies. Thus, regional business cycles do not play a significant role in explaining output volatility in the MENA region.

\section{References}

- $\quad$ Abed, G.T. and H.R. Davoodi (2003), 'Challenges of Growth and Globalization in the Middle East and North Africa', Washington, DC: International Monetary Fund.

- Aghion, P., G-M Angeletos, A. Banerjee, and K. Manova (2004), 'Volatility and Growth: Financial Development and the Cyclical Composition of Investment', MIT Working Paper, : MIT Press , Cambridge, Massachusetts.

- $\quad$ Ahmed, S., and P.N. Loungani (1998), 'Business Cycles in Asia', Working Paper, Board of Governors of the Federal Reserve System. 
- Aizenman, J., and B. Pinto (2005), Managing Economic Volatility and Crises: A Practitioner's Guide,Cambridge University Press, Cambridge.

- $\quad$ Al Zoubi, H.A. and M. Maghyereh (2005) 'Examining Complex Unit Roots in the MENA Countries Industrial Production Indices', Applied Economics Letters, Vol. 12, pp. 255-259.

- $\quad$ Berument, H., N.B. Ceylan and B. Vural (2007), 'The Effect of World Income on the Economic Performance of African Countries', International Journal of Economic Perspectives, Vol. 1, 183-94.

- Bjørnland, H.C. (1998), 'Economic Fluctuations in a Small Open Economy: Real versus Nominal Shocks', Statistics Norway Discussion Papers, vol. 215, ResearchDepartment of StatisticsNorway, Oslo.

- Blackburn, K. (1999), ‘Can Stabilisation Policy Reduce Long-Run Growth?’,Economic Journal, Vol .109, pp. 67-77.

- Blanchard, O.J. and D. Quah (1989), 'The Dynamic Effects of Aggregate Demand and Supply Disturbances', American Economic Review, Vol. 79, pp. 655-73.

- Diboglu, S. and E. Alesia (2004), 'Oil Prices, Terms of Trade Shocks, and Macroeconomic Fluctuations in Saudi Arabia', Contemporary Economic Policy, Vol. 22, pp. 50-62.

- Domaç, I. and G. Shabsigh (2001), 'Real Exchange Rate Behavior and Economic Growth in the Arab Republic of Egypt, Jordan, Morocco, and Tunisia', in Z. Iqbal (ed), Macroeconomic Issues and Policies in the Middle East and North Africa, : International Monetary Fund, Washington, DC.

- Doornik, J.A. and H. Hansen (1994), ‘A practical test of multivariate normality', unpublished paper, Nuffield College, Oxford.

- Glick, R. K. Rogoff (1995), 'Global versus Country-specific Productivity Shocks and the Current Account', Journal of Monetary Economics, Vol. 35, pp. 159-92.

- Hakura, D.S. (2004), 'Growth in the Middle East and North Africa', International Monetary Fund Working Paper 04, no. 56, : International Monetary Fund, Washington, DC.

- Hakura, D.S. (2007), 'Output Volatility in Emerging and Developing Countries', World Economic Outlook, International Monetary Fund, Washington, DC.

- Hamilton, J.D. (1989), 'A New Approach to the Economic Analysis of Nonstationary Time Series and the Business Cycle’, Econometrica, Vol. 57, pp. 357-84.

- Hamilton, J.D. (1994), Time Series Analysis, Princeton, New Jersey: Princeton University Press.

- Hirata, H., S.H. Kim and M.A. Kose (2004), 'Integration and Fluctuations: The Case of MENA', Emerging Markets Finance and Trade, Vol. 40, pp. 48-67.

- Hirata, H., S.H. Kim and M.A. Kose (2007), 'Sources of Fluctuations: The Case of MENA', Emerging Markets Finance and Trade, Vol. 43, 5-34.

- Hoffmaister, A.W. and J.E. Roldós (1997), 'Are Business Cycles Different in Asia and Latin America, IMFWorking Paper, vol. 97/9, International Monetary Fund, Washington, DC.

- Hoffmaister', A.W. J.E. Roldós (2001) 'The Source of Macroeconomic Fluctuation in Developing Country: Brazil and Korea', Journal of Macroeconomics, 23, pp. 213-39.

- Iqbal, Z., ed. (2001), Macroeconomic Issues and Policies in the Middle East and North Africa, International Monetary Fund, Washington, DC.

- Jalali-Naini, A.R. (2000), 'The Structure and Volatility of Fiscal Revenue in MENA Countries', Paper presented at the Third Mediterranean Development Forum, March 5-7, Cairo.

- $\quad$ Kose, M.A., C. Otrok and E.S. Prasad (2005) Regionalization vs. Globalization: Explaining North-South Business Cycle Dynamics, IMF Working Paper, International Monetary Fund, Washington, DC.

- Kose, M.A., C. Otrok and C. Whiteman (2003), 'International Business Cycles: World, Region, and Country-Specific Factors', American Economic Review, Vol. 93, pp. 1216-39.

- Laursen, T. and S. Mahajan (2005), 'Volatility, Income Distribution, and Poverty', in Managing Economic Volatility and Crises: A Practitioner's Guide, J. Aizenman and B. Pinto (eds), Cambridge University Press, Cambridge.

- $\quad$ Lucke, B. (2004), 'Real Interest Rates and Productivity Shocks: Why Are Business Cycles Negatively Correlated Between the European Union and Jordan?',Emerging Markets Finance and Trade, Vol. 40, pp. 82-94.

- Makdisi, S., Z. Fattah and I. Limam (2003), 'Determinants of Growth in the MENA Countries', Arab Planning Institute Working Paper 0301, Arab Planning Institute, Safat, State of Kuwait. 
- Mehrara, M. and K.N. Oskoui (2007), 'The Sources of Macroeconomic Fluctuations in Oil Exporting Countries: A Comparative Study’, Economic Modelling, Vol. 24, pp. 365-379.

- Nashashibi, K., M. Elhage and A. Fedelino (2001), 'Financial Liberalization in Arab Countries', in Z. Iqbal (ed), Macroeconomic Issues and Policies in the Middle East and North Africa, International Monetary Fund, Washington, DC.

- $\quad$ Phillips, K.L. (1991), 'A two-country Model of Stochastic Output with Changes in Regime', Journal of International Economics, Vol. 31, pp. 121-42.

- Shafik, N. (1998), Prospects for Middle Eastern and North African Economies: From Boom to Bust and Back?, St. Martin's Press, New York.

- Süssmuth, B. and U. Woitek (2004), 'Business Cycles and Comovement in Mediterranean Economies', Emerging Markets Finance and Trade, Vol. 40, pp. 7-27.

- Tamberi, M. (2005), Specialization and Growth Perspectives in the Mediterranean Countries. Paper presented at the Middle East and North African Economies: Past Perspectives and Future Challenges, June 2-23, Free University of Brussels.

- Tornell, A., F. Westermann and L. Martinez (2004), 'Liberalization, Growth and Financial Crisis: Lessons from Mexico and the Developing World', Brookings Papers on Economic Activity, Vol. 2003, 1-112. 